\title{
Generic Skills: Expectation and Reality
}

\author{
Sumaryati, $\mathbf{S}^{1}$, Joyoatmojo, $\mathbf{S}^{2}$, Anitah, S W ${ }^{3}$, Suryani, $\mathbf{N}^{4}$ \\ \{srisumaryati@staff.uns.ac.id \} \\ 1,2,3,4 Sebelas Maret University,Surakarta, Indonesia
}

\begin{abstract}
The objective of this study is to determine the level of generic skills owned by the students of Accounting Education Program. Its subjects were 73 students of Accounting Education Program, the Faculty of Teacher Training and Education, Sebelas Maret University. Questionnaire was used to its data, and the data were analyzed qualitatively. The result of the research shows that the students still have a low level of generic skills $(\leq 5.5)$. This is demonstrated by communication and presentation skills, technology and information utilization, numerical skills, working with others, as well as analytical skills and problemsolving skills that the students still have to improve (within the minimum or threshold category) when viewed from the criteria determined by the Quality Assurance Association (QAA) for Higher Education.
\end{abstract}

Keywords: generic skill,. accounting education

\section{INTRODUCTION}

The technological change framework, labor demand development, and, sustainable institutional transformation, employment providers, one of which is company, take strenuous efforts to get or hire competent and skillful employees. As users of university graduates, the government, business people, and other employers link their demand standards to the level of skills and competences obtained by the graduates of Higher Education (HE) and with the overall State welfare [1]. Therefore, the Bachelor's Degree Program in Accounting Education as a part of the higher education is responsible for supplying skillful employees who are able to compete not only in technical skills, but also in generic skills. It is believed so since the students having adequate generic skills will have more opportunities in entering the workforce, making them more flexible in facing challenges of globalization and the future, and also enabling them to work together with the present technological advances. [2],[3],[4]. On the contrary, prospective employees who do not have sufficient skills needed by the employers, will experience difficulties in engaging in workforce competition. This, in turn, will cause a serious problem to a country [5],[6].

Considering the importance of generic skills, one thing which should be understood by all educators in an effort to improve generic skills of university students is by growing the generic skills through learning [7],[8]. To put it into learning, teachers should consider the characteristics of generic skills themselves, in which they can be taught in various disciplines and are inherent on all subject matters. This means that the generic skills can be taught in all courses, in accordance with their respective nature and features [4]

The difference in nature of generic skills corresponding to each field of work causes the generic skills needed by each student to be different [2],[9]. Users of Accounting Education graduate in various countries need skillful employees suited to their field of work. 
Table 1.Generic Skills Needed of Accounting Education Graduate in Various Countries

\begin{tabular}{|c|c|c|c|}
\hline No. & Countries & Generic Skills Needed & Researchers \\
\hline 1. & Sri Lanka & $\begin{array}{l}\text { Intellectual skills and personal qualities, analytical } \\
\text { skills, communication skills, and accounting and } \\
\text { technical skills }\end{array}$ & $\begin{array}{l}\text { Abayadeera and Watty } \\
(2014)\end{array}$ \\
\hline 2 & Australia & $\begin{array}{l}\text { Literacy/numeracy, ICT, thinking skills, creativity, } \\
\text { self-management, teamwork, intercultural } \\
\text { understanding, ethical behavior, and social } \\
\text { competence. }\end{array}$ & $\begin{array}{l}\text { Kavanagh and Drennan } \\
(2008) \\
\text { Bowman (2012) }\end{array}$ \\
\hline 3 & Malaysia & $\begin{array}{l}\text { Information analyzing, working in team skills, } \\
\text { problem-solving skills, long-life learning skills, skills } \\
\text { in using technology, entrepreneurial skills, creative } \\
\text { and critical thinking skills, and leadership and } \\
\text { personal qualities. }\end{array}$ & $\begin{array}{l}\text { Rahman, Mokhtar, Yasin } \\
\text { \& Hamzah, (2011) } \\
\text { Singh., Thambusamy, } \\
\text { \&Ramly, } 2014\end{array}$ \\
\hline 4 & New Zealand & $\begin{array}{l}\text { Communication, information management skills, } \\
\text { personal management, physical and numerical skills, } \\
\text { problem solving skills, working in teams skills. }\end{array}$ & Bowman (2012) \\
\hline 5 & Nigeria & $\begin{array}{l}\text { Critical thinking skills, communication } \\
\text { information technology skills, analytical } \\
\text { skills, } \\
\text { decision making skills, problem-solving skills, } \\
\text { interpersonal skills, independent learning skills, } \\
\text { technical, entrepreneurship, and numerical skills }\end{array}$ & Pitan (2015) \\
\hline
\end{tabular}

There are many experts in Indonesia who interpret it as transferable skills. In this research, several transferable skills which should be developed through learning, namely: (1) the ability to communicate effectively in work team; (2) the ability to negotiate to produce win-win solutions; (3) the ability to assess IT use correctly; (4) the ability to work in a team by obeying job division and responsibilities; (5) the ability to respect others based on his/her competencies; (6) the ability to lead a team in a just and democratic manner [10]. Based on the information above, the objective of this study is to investigate the image of generic skills of the students of Accounting Education program, the Faculty of Teacher Training and Education, Sebelas Maret University, so that it can be made a foundation for lecturers and decision makers related to quality human resources, especially on Accounting Education graduates.

\section{RESEARCH METHOD}

This research used survey and explorative research methods to obtain various kinds of information regarding the students' generic skills, which may be developed through the improvements in learning quality of accounting so that they will be directed to the improvement of students' generic skills as a component of prospective employees in the era of globalization. Its subjects were 72 students of Bachelor's Degree Program in Accounting Education of $1^{\text {th }}$ semester.

The procedures taken to achieve the purpose were identifying through declaring the levels of the students' generic skills, by comparing them to the internationally-applied standards (benchmark statements stated by QAA for HE),[11], so that it can be identified, whether the subjects' generic skills were classified into minimum stage (threshold), good stage (modal), or best stage. 


\section{RESULTS AND DISCUSSION}

The result of the analysis shows that in general, the generic skills of the students still need to be improved as indicated by the data obtained and presented in Table 2.

Table 2. Average Level of Generic Skills of The Students of Accounting Education Program

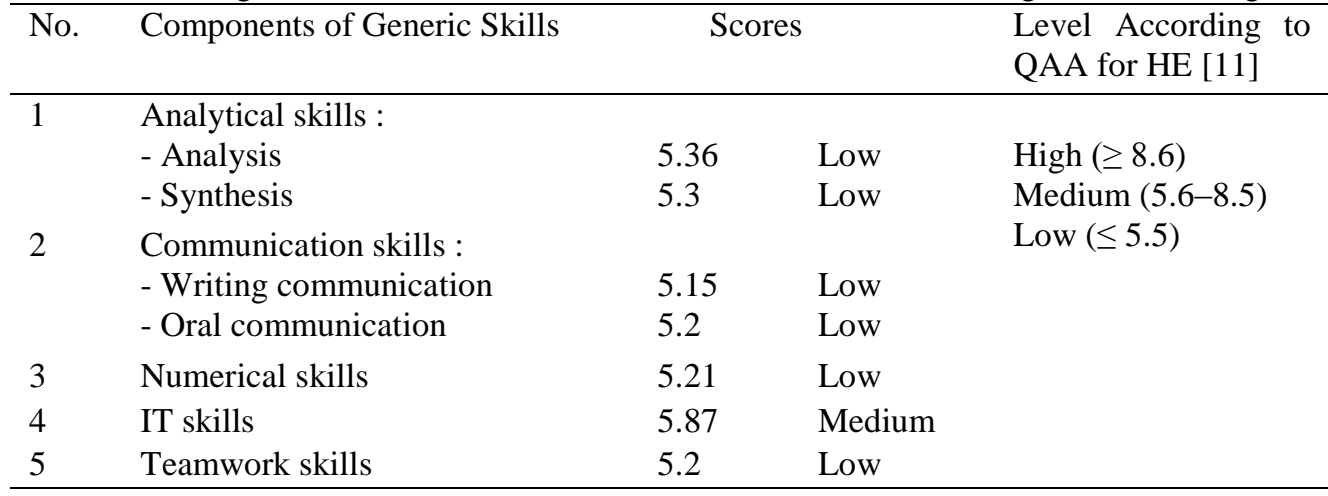

Based on Table 2, the students' analytical and problem-solving abilities still need to be improved as indicated by the low level of analytical skills of the students in using and synthesizing empirical and theoretical data in order to be useful information to others to solve the problems that they encounter. Even though if compared to the Quality Assurance Association for Higher Education the students' analytical abilities were still included in the low category, but their abilities to make new synthesis from the theoretical studies collected were included in the low category.

This should concern the educators, since there are many researchers stressing the analytical abilities in modern accounting world, so that the graduates are able to compete and survive in the midst of changes occurring in a high speed [12],[13],[14],[15],[16]. If viewed from the employers' point of view, the employers expect graduates in Accounting to have the analytical abilities, since such abilities are required for obtaining information, filtering, selecting, and presenting information in a correct manner, as well as evaluating the truthfulness of the information itself [14],[15]. Thus, an individual should be able to select sources and methods used correctly, so that s/he may be able to investigate types of information required, and to access information needed in an effective and efficient manner. Besides that, the students will be able to evaluate information and its sources critically, to combine selected information to be the base of someone's knowledge, to use information effectively to achieve certain purposes, to understand economic, legal, and social issues related to information usage, and to access and use information in an ethical and legal manner.

Based on the data obtained, the communication abilities of the students should be improved more. On average, the oral communication abilities of students were included in the low category, meaning that the students were not yet able to argue in team and to present their opinion in public, and therefore the abilities of students to teach knowledge or skills to others should be improved. In line with oral communication, the average level of the students' written communication abilities was included in the low category. The students did not has acquired the abilities to produce free-writing in mass media and the abilities to write scientific publications.

Similarly, the students' communication ability need to be improved since it is one of the important components of generic skills. There are some considerations in this argument. The 
communication skills are important because, by possessing the skills, one can identify the function of communication itself, and determine the ways, styles, and techniques of communication correctly so that s/he can get feedback from his/her audience [17]. Siriwardane, Low, \& Blietz explained that "the three most important communication skills include listening responsiveness, listening attentiveness, and reading comprehension. The three least important skills include conducting an interview (interviewer), negotiating, and facing an interview (interviewee)"[18].

In addition to some skills discussed before, the technological utilization skills are also needed by an individual, since technological ability is useful to obtain information needed in achieving the intended purposes. Bawdeen defined technological utilization skills in a number of terms such as information literacy, computer literacy, digital literacy, network literacy, and media literacy [19]. Based on the data obtained, the students' ability in using computer to process words, to edit scientific publication manuscript, and to operate internet in general was included in the medium category, although on average, the level of the students' ability in the utilization of computer and internet facilities such as searching, troubleshooting, choosing software which will be used, and the ability to develop database had a low score and was included in low category. The ability of using technology has to be possessed by students, along with the development in science and technology. One who possess this skill will be able to operate computer, to use computer programs, to read and understand digital texts, and to use operating system and software which support his/her work such as Microsoft Word, Spreadsheet, Presentation software, Internet, and various research and picture-related software [19],[20].

Based on table 2, it is known that the students' numeric skills were included in minimum category (threshold). This indicates that on average, students were not able to interpret graphs as the result of data analysis. Students, averagely, also had a low level of ability in testing statistical hypothesis for research and in interpreting data analysis result by using some software such as SPSS, MYOB Accounting or the similar. Even so, the students generally had medium ability in doing works of accounting such as financial bookkeeping, financial analysis, making business planning, and making rational budget to initiate certain projects or activities.

Other skills which are not less important are teamwork skills. Teamwork skills are exceptionally needed by an individual working in a team. This happens since in teamwork, one should be able to provide and receive inputs from others in achieving the stated goals, to motivate others, to solve conflicts in the team, to delegate tasks to others, and to lead the team [21]. It was known that the students' teamworks skills were still in the category of minimum (threshold). This shows that the students still need some guidance. Some experts believe that the teamwork skills not only are needed by an individual, but also are the responsibility of the team. This is what the employers need from higher education graduates; not only having technical skills, but also showing generic skills such as team skills and leadership [22],[23].

Overall, based on Table 2, the condition of generic skills owned by the students of Bachelor's Degree Program in Accounting Education, the Faculty of Teacher Training and Education, Sebelas Maret University, was still considered as low. By looking at the condition, it is a matter of fact that educators should begin to think of a learning process which can accommodate the improvements of students' generic skills so that the graduates can become employees who have a high competitive advantage. The efforts to improve generic skills can be conducted through learning. Some researchers recommended to integrate generic skills into each learning, to use portfolios of each student, to apply blended learning method [4],[24] and also to conduct learning by using Peer-Assisted Learning strategy [25],[26],[27]. 


\section{CONCLUSIONS}

It is agreed by the users of Higher Education graduates that the optimization of generic skills is a non-negotiable matter. It is known from the research that the level of generic skills of the students of Accounting Education Program still needs to be improved. The analytical skills, problem-solving skills, communication skills, teamwork skills, IT skills, and numerical skills are the skills that require development in Higher Education, so that its graduates will be more able to compete in global markets through intra-curricular and extra-curricular activities, among others. This becomes the responsibility of lecturers to design learning which will improve the students' generic skills.

\section{REFERENCES}

[1] Asonitou S 2014 Employability Skills in Higher Education and The Case of Greece. Procedia-Social and Behavioral Sciences 175, pp. 283-290

[2] Yusof Y, Roddin R, \& Awang H 2015 What Students Need, and What Teacher Did: The Impact of Teacher's Teaching Approaches To The Development af Students' Generic Competences, Procedia-Social and Behavioral Sciences 204 pp. 36-44

[3] Paadi K 2014 Perceptions on Employability Skills Necessary To Enhance Human Resource Management Graduates Prospects of Securing A Relevant Place in The Labour Market, European Scientific Journal August 2014 /SPECIAL/Edition ISSN: 1857 - 7881 (Print) E - ISSN 1857- 7431

[4] Al-Alawneh M K 2011 Vocational Education Graduates' Generic Kills as Perceived by Educators and Employers in Jordan Labor Market, The IUP Journal of Soft Skills, V, 2.

[5] Roy C 2013 Rethinking Generic Skills, European Journal For Research on The Education and Learning of Adults 4.2, S. pp.129-138

[6] Sutherland 2012 Qualifications Mismatch and Skills Mismatch", Education + Training, 54 Issue: 7, pp.619-632

[7] Oria B 2012 Enhancing Higher Education Students' Employability: A Spanish Case Study. International Journal of Technology Management \& Sustainable Development 11.3

[8] Singh P, Thambusamy R X, Ramly M A 2014 Fit or Unfit? Perspectives of Employers and University Instructors of Graduates'Generic Skills, Procedia - Social and Behavioral Sciences 123. pp. $315-324$

[9] Bowman 2012 Background Paper For The AQF Council On Generic Skills , www.Aqf.edu.au/Wp-Content/Uploads/.../Generic-Skills-Background-Paper-Final.Pdf

[10] Siswandari \& Susilaningsih 2008 "Pengembangan Transferable Skills Mahasiswa Melalui Peningkatan Kualitas Pembelajaran Statistika Dalam Rangka Meningkatkan Daya Saing Lulusan Pendidikan Tinggi”. Research Report of Competitive Grant XIV Year I. DP3M of Higher Education of the Republic of Indonesia

[11] QAA 2015 Subject Benchmark Statement, Education Studies, Part A : Setting and Maintaining Academic Standards, UK Quality Code for Higher Education

[12] Mallak M A 2012 Accounting Students' Need For Important Generic and Technical Accounting Skills In University Education and As Accountants In The Workplace., A Thesis Submitted In Fulfilment Of The Requirements For The Degree At The University Of Waikato 
[13] Sugahara \& Coman 2010 Perceived Importance of CPA's Generic Skills: A Japanese Study. Asian Journal of Finance \& Accounting 2(1): pp.1-24.

[14] Awayiga J Y, Onumah J M, \& Tsamenyi M, 2010 Knowledge and Skills Development of Accounting Graduates: The Perceptions of Graduates and Employers In Ghana., Journal Accounting Education 19, Issue 1-2

[15] Kavanagh \& Drennan 2008 What Skills and Attributes Does An Accounting Graduate Need? Evidence From Student Perceptions and Employer Expectations, Onlinelibrary.Wiley.Com/Doi/10.1111/J.1467-629X.2007.00245.X/Abstract

[16] De Lange Jackling \& Gut 2006 Accounting Graduates Perceptions of Skills Emphasis in Undergraduate Courses: An Investigation From Two Large Victorian Universities, Accounting and Finance, 46 (3),pp. 365-386.

[17] Mayer 1992 Key Competencies: Report of the Committee to Advise the Australian Education Council and Ministers of Vocational Education, Employment and Training on Employment-Related Key Competencies For Postcompulsory Education And Training [Mayer Report]., [Canberra:1992

[18] Siriwardane Low, \& Blietz 2015 Making Entry-Level Accountants Better Communicators: A Singapore-Based Study Of Communication Tasks, Skills, and Attributes., Journal of Accounting Education 33, Issue 4 pp. 332-347

[19] Karasavvidis \& Theodosiou 2014 The Use of Digital Texts As An Alternative Method of Determining Functional ICT Literacy Levels , International Journal Of Digital Literacy and Digital Competence, 5(4), 19-32

[20] Hahnel, Goldhammer, Naumann, \& Krohne 2015 Effects of Linear Reading, Basic Computer Skills, Evaluating Online Information, and Navigation on Reading Digital Text. Computers in Human Behavior, 55, Part A, pp. 486-500

[21] Smith S, Farra S, Ten Eyck R, \& Bashaw M 2015 Development of an Instrument to Measure Nursing Student Teamwork Skills. Clinical Simulation in Nursing. 11, 507-512

[22] Riebe, Roepen, Santarelli \& Marchioro 2010 Teamwork: Effectively Teaching an Employability Skill", Education + Training, 52 Iss 6/7 pp. 528 - 539

[23] Delaney, Fletcher, Cameron \& Bodle 2013 Online Self and Peer Assessment of Team Work in Accounting Education", Accounting Research Journal, 26 Issue: 3, pp.222-238

[24] Luca J \& Oliver R 2011 Developing An Instructional Design Strategy To Support Generic Skills Development, Proceedings of The 19th Annual Conference Of The Australasian Society For Computers In Learning In Tertiary Education. Auckland, New Zealand, ECU Publications Pre.

[25] Sampaio P N M, Teixeira J M, Camacho M F, \& De Freitas Gouveia R H 2011; Blended Peer-Assisted Learning Platform: Improving Learning Outcomes With A Collaborative Environment., J. Educational Technology Systems, 39(4) 371-395

[26] El Tantawi M M A, Abdelaziz H, Abdelraheem A S, \& Mahrous A A 2014; Using Peer-Assisted Learning And Role-Playing To Teach Generic Skills To Dental Students: The Health Care Simulation Model., Journal Of Dental Education 78 No. 1 pp.85-97

[27] Malone M, \& Morrissey S 2014 Peer Learning: Student-Centered Instructional Strategy For The Development of Critical Thinking and Generic Skills. International Conference On Engaging Pedagogy (ICEP), Athlone Institute Of Technology, Co. Westmeath, Ireland, Dec. 5, 2014

[28] Rahman, Mokhtar, Yasin \& Hamzah 2011 Generic Skills Among Technical Students In Malaysia , Procedia Social And Behavioral Sciences 15 pp. 3713-3717"

[29] Pitan O S 2015 An Assessment of Generic Skills Demand In Five Sectors of The Nigerian Labor Market, Public And Municipal Finance Journal, 4, Issue 1 
